\title{
Is Formal Language Proficiency in the Home Language Required to Profit from a Bilingual Teaching Intervention in Mathematics? A Mixed Methods Study on Fostering Multilingual Students' Conceptual Understanding
}

\author{
Alexander Schüler-Meyer ${ }^{1}$ (D) Susanne Prediger $^{1}$. \\ Taha Kuzu $^{1}$ • Lena Wessel ${ }^{2} \cdot$ Angelika Redder $^{3}$
}

Received: 24 October 2016 / Accepted: 9 September 2017 / Published online: 10 November 2017 (C) The Author(s) 2017. This article is an open access publication

\begin{abstract}
To what degree can multilingual students profit from bilingual tea ching approaches, even when they lack experience in the academic or technical register in their home languages? This study explores this research question in a mixed methods design for a German/Turkish bilingual intervention aimed at
\end{abstract}

Alexander Schüler-Meyer

alexander.schueler-meyer@math.tu-dortmund.de

Susanne Prediger

prediger@math.uni-dortmund.de

Taha Kuzu

taha.kuzu@tu-dortmund.de

Lena Wessel

lena.wessel@ph-freiburg.de

Angelika Redder

angelika.redder@uni-hamburg.de

1 Faculty of Mathematics, Institute for Development and Research in Mathematics Education (IEEM), 44221 Dortmund, Germany

2 Institute for Mathematics Education Freiburg, University of Education Freiburg, 79117 Freiburg, Germany

3 Faculty of Humanities, Department for Language, Literature, Media, Institute of German Philology, University of Hamburg, Von-Melle-Park 6, 20146 Hamburg, Germany 
fostering conceptual understanding of fractions (five sessions of 90 min each). The sample consisted of German/Turkish bilingual students $(n=128)$ in Grade 7 in German schools without prior formal mathematics education in Turkish. In a randomized control trial, the bilingual intervention was compared to the corresponding monolingual intervention and a control group. A repeated ana lysis of variance (ANOVA) showed that students in both interventions had significantly higher learning gains than in the control group, and in fact profited equally from both interventions, although some time and effort was required for overcoming initial barriers in the home language and especially in the academic register. A qualitative analysis of the videotaped bilingual learning processes revealed insights into specific obstacles and chances of connecting both languages in order to foster conceptual understanding. The students with some formal language proficiency in Turkish seemed to profit even more from the bilingual intervention, but a rigid technical register was not necessary.

Keywords Bilingual teaching intervention in mathematics $\cdot$ Formal language proficiency $\cdot$ Learning of fractions $\cdot$ Randomized control trial

\section{Introduction}

There is a persisting mathematics achievement gap between monolingual and multilingual learners, with research in some countries dating back more than 30 years (see Secada, 1992, for early summaries). For other countries, this gap has been acknowledged more recently and traced back to a limited language proficiency in the official language of instruction (Haag, Heppt, Stanat, Kuhl \& Pant, 2013; Organisation for Economic Co-operation and Development [OECD], 2007).

One major approach for facilitating access to subject-matter learning for multilingual learners is to build upon their home languages as a resource (Barwell, 2009; Gogolin, 2011; Grießhaber, Özel \& Rehbein, 1996). When offering bilingual teaching programs to multilingual students in secondary mathematics classrooms, one typical obstacle is the limited familiarity with formal (i.e. academic or technical) registers in the students' home language. This specifically applies to minority-language students initially schooled only in the official language. This article theoretically and empirically explores this issue by investigating how much proficiency in the formal registers of the home language is required for participa ting in and profiting from a bilingual teaching intervention on fractions. This research was pursued in a German/Turkish bilingual teaching intervention in Grade 7 that aims at deepening the conceptual understanding of fractions.

In the first section, the theoretical and empirical background of bilingual teaching programs and the role of formal language registers are presented. The second section outlines the research context, namely the German language context and the teaching intervention investigated. The mixed methods design of the study with a randomized control trial and qualitative video analysis from the teaching-learning processes are reported in the third section and the quantitative results and first qualitative insights in the fourth section. 


\section{Background: Bilingual Teaching Programs and the Role of Formal Language Registers}

\section{Benefits and Obstacles of Activating Students' Home Languages}

In many European countries, bilingual teaching programs are discussed controversially (summarized in Meyer, Prediger, César, \& Norén, 2016). Although the Council of Europe pleads for including students' home languages in subject-matter courses (Beacco, Byram, Cavalli, Coste, Egli Cuenat, Goullier \& Panthier, 2010), most European school systems are still reluctant to open their monolingual classrooms to home languages (Meyer et al., 2016).

The state of research on the benefits of including home languages is not yet consistent. Several qualitative studies on bilingual mathematics learning processes have illustrated that students' home languages can be a resource for mathematics learning in various ways, such as participating in mathematical discourses (Planas, 2014), activating everyday out of school experiences (Domínguez, 2011), upgrading resources for meaning making processes (Clarkson, 2006; Norén, 2015), and others (Barwell, 2009, for several possible effects). However, little quantitative evidence exists: Some randomized control trials have provided evidence for the higher efficacy for bilingual teaching programs for other school subjects (Slavin \& Cheung, 2005, although many have been criticized for methodological biases; see Rossell \& Kuder, 2005), but for mathematics learning, this evidence has not yet been con-vin-cing (Reljić, Ferring \& Martin, 2015).

Two main arguments have often been raised against bilingual teaching programs: First, a simple time-on-task argument proposes that home languages and official languages may compete for students' scarce time resources, while maximum exposure to a language is crucial (Gathercole, 2002; Leseman, Scheele, Mayo \& Messer, 2009); this argument, however, has been refuted by others (e.g. Cummins, 2000; MacSwan \& Rolstad, 2010). The second argument has referred to multilingual students' limited familiarity with the formal register in their home language (L1, for this paper Turkish): Students who have only been schooled in the official language of instruction (L2; German, in this paper) and not in L1, the formal register (encompassing the academic school register as well as the technical register of school subjects; see next section) in L1 has been developed with limited proficiency and is dysfunctional for school learning (Grosjean, 2001). Accordingly, home languages have been questioned in their role as means of participating in classroom mathematical discourse or a resource to build on to foster the formal registers in the official language (Barwell, 2009; Snow \& Uccelli, 2009). Teaching in two languages can result in a tension between activating multilingual resources and fostering the appropriation of formal language (Adler, 2001). Hence, in spite of the qualitative indications for potential benefits of activating students' home language in mathematics, the assumed need to develop some aspects of the academic and technical register in the home language may raise a more complex time-on-task concern (adapted from Gathercole, 2002): Time for learning mathematics may be competing with time for learning formal registers in the home language. This must therefore be investigated more deeply. 


\section{Fostering Formal Language Learning in Mathematics Classrooms}

The role of the formal registers in learning processes can be conceptualized by a unified model of representations and registers (see Fig. 1), as suggested by Prediger and Wessel (2013) and Prediger, Clarkson, and Bose (2016). Classically, mathematics learning was described as navigating between the graphical, verbal, and symbolic representations (Duval, 2006; Lesh, 1979).

The verbal representation is differentiated in two times three registers: the everyday register (with familiar vocabulary and simple sentence structures), the academic school register (which has been described by the more complex vocabulary and structures on the sentence and discourse level; see Schleppegrell, 2004; Snow \& Uccelli, 2009), and the technical register of mathematics (comprising the specialized language means specific to mathematics), each in the home language L1 and the official language of instruction L2.

On a prescriptive level, the mathematics learning of language learners can be fostered by systematically relating all registers and representations in both languages (Moschkovich, 2013; Prediger et al., 2016). On a descriptive level, multilingual students' limited familiarity with the formal registers in the home language may thus be a key to explaining why bilingual teaching programs may not be immediately beneficial for some multilingual students: Students with few experiences with the formal register in their home languages may have fewer resources for learning the formal language in the language of instruction, as the home language is less likely to be the take-off point (Setati \& Adler, 2001). However, no intervention study has compared learning gains for different home language proficiencies, and no differentiation between the academic and the technical register has been provided. On an empirical level, this study investigates the connection between learning gains and home language proficiency. With the presented research findings, we hypothesize that students with higher language proficiency may profit more, as they have more time to work mathematically and have more resources to meaningfully connect to formal language. While we acknowledge the high relevance of the home language everyday register (Moschkovich, 1999, 2002; Setati, 2005), we follow Adler (2001) in assuming it may not be sufficient for an immediate participation in classroom mathematical discourses. The adapted time-on-task concern may be specifically significant in a short-term teaching intervention, where-with L1 being dysfunctional for school learning - time is needed for overcoming L1 barriers. This leads to questions of how and to what degree adolescents who are familiar with

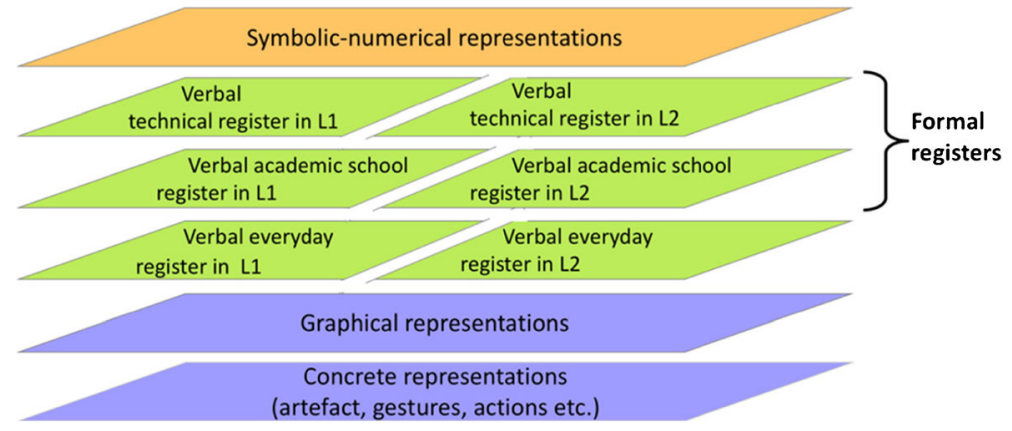

Fig. 1 Model of relating different representations and registers for mathematics learning (Reproduced with permission from Prediger et al., 2016; Prediger \& Wessel, 2013) 
monolingual classrooms can be encouraged to activate their home language resources and whether it is possible to overcome initial barriers (Meyer \& Prediger, 2011).

\section{Refined Research Questions}

Based on the current state of research, the research question can be refined for our study with multilingual German/Turkish students in Grade 7 socialized in a German-only school who have varying proficiency in Turkish formal registers. The dependent variable to be considered is conceptual understanding of fractions:

(Q1) How can bilingual teaching-learning situations be established in which multilingual students, who have never used their home languages in school, can activate these languages?

(Q2) How do the learning gains (for the conceptual understanding of fractions) differ between the bilingual intervention, the monolingual intervention, and the control group?

(Q3) How do the learning gains differ for students with high or low Turkish formal language proficiency?

The instruction design of the intervention, which will be presented in the next section, is a first answer for Q1; it was developed in previous design research cycles (see next section; Kuzu 2014, unpublished; Prediger \& Wessel, 2013). In this paper, we provide results from a quantitative video analysis of students' and teachers' use of Turkish during the intervention as empirical evidence for the realizability of late start in bilingual instruction. For Q2 and Q3, a randomized control trial is conducted and triangulated, especially for Q2, using qualitative insights into the learning processes.

\section{Research Context and Design of the Teaching Intervention}

\section{German Language Context}

The research questions (among others) were pursued in the project MuM-Multi (funded by the German ministry BMBF, grant 01JM1403A, held by Prediger, Redder, Rehbein).

More than $25 \%$ of the students in German schools are multilingual (Haag et al., 2013); however, so far, multilingual teaching programs are rare. Here, we explore a bilingual program for the largest language minority group: German/Turkish bilingual students. Most of these students were born in Germany and schooled in German, and only a minority learn Turkish formal language at home (Daller, 1999). In our sample, most may have no experience with mathematics in Turkish; even homework is often done in German (as revealed by the questionnaire data).

\section{Design Principles and Realization of the Teaching Intervention}

The research questions were pursued in a German/Turkish bilingual teaching intervention in Grade 7 aimed at deepening conceptual understanding of fractions (part-ofwhole concept, equivalence, and order of fractions). The intervention comprised five 
sessions of $90 \mathrm{~min}$. each, which is a relatively short time to adapt to a new multilingual situation.

Three design principles for language- and mathematics-integrated classrooms were applied to adapt a well-evaluated German monolingual intervention for fostering conceptual understanding of fractions (Prediger \& Wessel, 2013) to a bilingual intervention (shown in Table 1). The monolingual intervention was based on these design principles: Providing rich opportunities for language production (Swain, 1985); macro-scaffolding, i.e. carefully sequencing the learning opportunities along a conceptual and lexical learning trajectory (Gibbons, 2002); and relating registers by continuously moving up and down in the registers and representations (as depicted in Fig. 1) instead of proceeding from informal to formal language in a single big move without coming back to students' everyday resources (Prediger et al., 2016). In a preceding design research project (Kuzu 2014, unpublished), the same monolingual intervention was adapted to a bilingual intervention. Again, the students' resources are starting points in a trajectory moving towards formal languages, concepts, and procedures, and the basic idea is that the home languages can be used best if they are systematically and continuously connected to all other registers.

In order to help students overcome obstacles with the formal register in both languages, a macro-scaffolding approach (Gibbons, 2002) was extended to provide phrases for discourse

Table 1 Design principles for adopting a bilingual intervention

Monolingual intervention

Principle of creating rich opportunities for communication and language production

- following the output hypothesis (Swain, 1985), language production is encouraged in teacher-moderated small groups

- micro-scaffolding moves to foster students' pathways along the language registers

Principle of macro-scaffolding (Gibbons, 2002)

- constructing meanings for concepts by starting the conceptual learning trajectory with everyday contexts and visual models (Freudenthal, 1991)

- sequencing the conceptual learning trajectory from everyday resources to formal concepts and formal procedures (Freudenthal, 1991)

- enriching the conceptual learning trajectory with language-learning opportunities from everyday language to the technical register (Gibbons, 2002)

Principle of relating registers and representations

- systematically moving forward and backward between all registers and representations for constructing meanings

(see Fig. 1)

- initiating various activities for relating registers and representations (Prediger \& Wessel, 2013)
Added or adopted for bilingual intervention

Creating opportunities for bilingual communication and Turkish language production

- doing small group work also crucial for engaging multilingual learners (Planas \& Setati, 2009; Grießhaber et al., 1996)

- due to missing Turkish math experience, encouraging Turkish language production systematically (Meyer \& Prediger, 2011)

Developing the Turkish formal registers and taking into account culturally sensitive contexts

- showing also the relevance of contexts for multilingual students, especially for contexts stemming from language-specific, non-dominant communities (Domínguez, 2011)

- additionally, developing Turkish formal registers as far as necessary

- in particular, establishing meaning-related vocabulary, based on an analysis of Turkish mathematical vocabulary (Kuzu 2014, unpublished)

Additionally, relating both languages

- relating home and official language by encouraging code-switching and strategies of relating languages in bilingual modes (Auer, 2010; Grosjean, 2001)

- bilingual co-presence of all material in German and Turkish (Setati, Molefe \& Langa, 2008)

- systematically comparing expressions for concepts in both languages to deepen conceptual understanding 
practices in both languages. For example, we introduced the word düşen pay in Turkish (share in English) when communicating about a "part of a whole." In a fraction bar, a part can be shown as a gray area within a whole (full-length bar), but students should also have the possibility of reifying the part-of-a-whole concept in a single word.

In Turkish mathematics textbooks, no adequate meaning-related word was found (which hints at culturally specific Turkish teaching practices that differ from German practices; see Clarke, 2013). An invented Turkish meaning-related phrase to explain this concept was introduced to establish teaching practices that are compatible with German practices. Other examples for existing Turkish words and phrases and their corresponding German words are collected in Table 2.

The main principle of flexibly moving up and down between the registers and representations also refers to the connection between the two languages: Rather than only activating both languages separately and accepting code-switching, it is the connection of languages that may be most promising for promoting deeper understanding (House \& Rehbein, 2004). Although previous instruction on fractions was only in German, activating the Turkish language in order to promote conceptual understanding may help students to think mathematically by activating everyday experiences about fractions (see Domínguez, 2011). Furthermore, it acknowledges that multilingual resources are best addressed not as separate languages, but by translanguaging and flexibly connecting both languages (House \& Rehbein, 2004). To overcome habitual monolingual practices, the teachers spoke a flexible mix of languages and revoiced students' German utterances into Turkish or mixed language (see Setati \& Adler, 2001, p. 265).

Furthermore, the bilingual teaching intervention comprised activities designed to help students reflect on diverging expressions for mathematical concepts, such as the reading direction of fractions (Bartolini Bussi, Baccaglini-Frank \& Ramploud, 2014): The Turkish way of expressing fractions such as $\frac{3}{5}$ as " 5 -te 3 " corresponds to the Asian (e.g. Mandarin) reading direction from down to up in the numeric way of writing a fraction, literally translated "5 therein 3." In comparing it to the German "3 5-tel" (translated as "three fifths"), with the reading direction from up to down, the students reflect that the focus on the referent whole in "5 therein 3" is closer to relevant meanings than in German. This contrasting activity allows a deepened understanding of fractions (as shown in Wagner, Kuzu, Redder, \& Prediger, 2017).

Table 2 Examples for important meaning-related lexical means in German and Turkish

\begin{tabular}{|c|c|}
\hline German & Turkish \\
\hline 3/5: Spoken as "3 5-tel”" (three fifths) & $\begin{array}{l}\text { 3/5: Spoken as " } 5 \text {-te } 3 \text {," specific Turkish conceptualization } \\
\text { of the fraction as " } 5 \text { therein } 3 \text { " }\end{array}$ \\
\hline $\begin{array}{l}\text { Anteil = share: A specific German word } \\
\text { for thinking about "part of whole" }\end{array}$ & $\begin{array}{l}\text { düşen pay: The Turkish expression (meaning "the part that } \\
\text { one gets") was newly created due to missing correspondents }\end{array}$ \\
\hline Teil and Ganzes = "part" and "whole" & parça and bütün \\
\hline kleiner/größer als = "smaller/bigger than" & daha büyük/daha küçük, daha büyük/küçük düşen pay \\
\hline $3 / 5$ von $\ldots$ ist $\ldots=$ " $3 / 5$ of $\ldots$ is $\ldots "$ & $\begin{array}{l}\text { 'ün/nın/in } 5 \mathrm{de} \text { 3'u/ü/l ...: Turkish has a different order of } \\
\text { sentence elements and suffixes (due to the suffix-vocal } \\
\text { harmony) ("of } 5 \text {, there is } 3 \text { ") }\end{array}$ \\
\hline
\end{tabular}


Summing up, the monolingual as well as the parallel bilingual teaching intervention aims at enhancing students' conceptual understanding of fractions by providing a language- and mathematics-integrated learning opportunity in which the conceptual learning trajectory is supported by sequenced language learning opportunities along the registers. The bilingual contains all elements of the monolingual intervention, and additionally strengthens the activation and combination of both languages by extending the relating registers approach to the home language in all registers.

\section{Research Design and Methodology}

\section{Overview of the Mixed Methods Design}

In order to pursue the research questions and investigate the role of formal language proficiency in the home language for mathematics learning in a bilingual intervention, this research study was conducted using a mixed methods design. The quantitative part of Q2 and Q3 was realized in a randomized control trial with students' conceptual understanding of fractions as the dependent variable and language proficiency in German and Turkish, socioeconomic status (SES), and fluid intelligence as control variables. For the independent variable, the teaching intervention varies between monolingual and bilingual Turkish/German intervention and a control group (regular mathematics classroom without additional treatment) (see Fig. 2).

The video data from the bilingual intervention groups offer the data corpus for the time measurement of Turkish use (Q1) and the qualitative analysis for pursuing Q2 and Q3 on the micro-level of the learning processes.

\section{Preparation of Teachers and Video Data Corpus}

The monolingual and bilingual teaching interventions encompassed five sessions of 90 min each. They were held in groups of 3 to 5 students by well-trained teachers in the

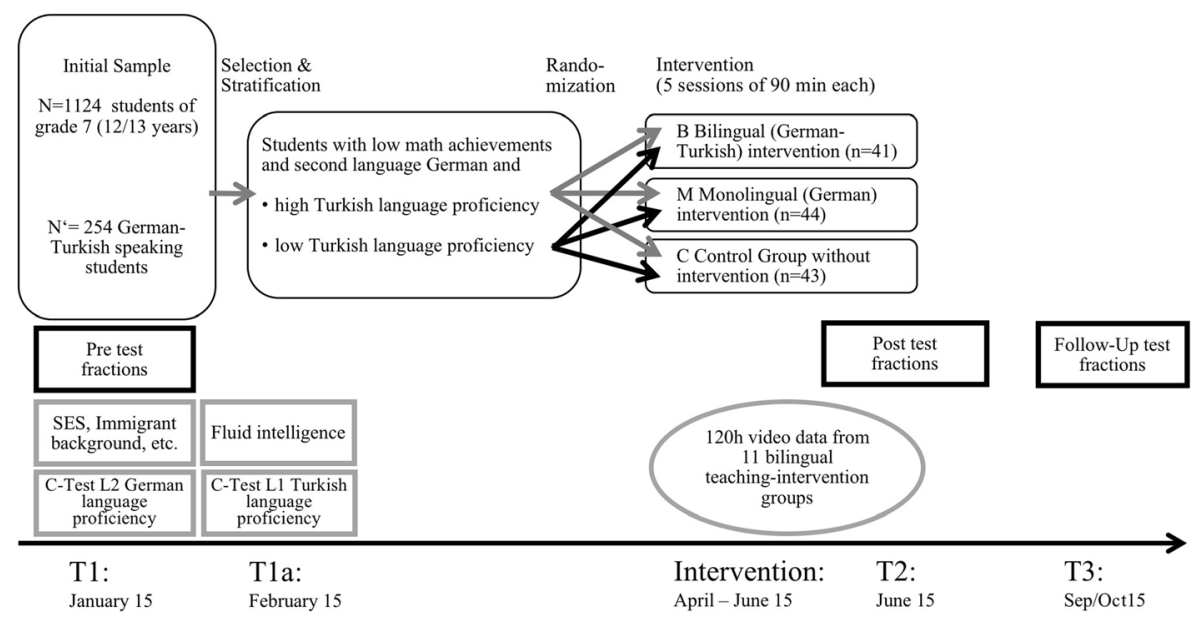

Fig. 2 Mixed methods design with a randomized control trial and qualitative video analysis of the intervention 
master's program of mathematics education. These teachers were specifically qualified in the linguistics and didactical concerns of the interventions in a two-day workshop on the principles of the teaching intervention (see above). Regular meetings between the interventions guaranteed the comparability of both intervention programs. The bilingual interventions were videotaped in all 11 groups, 5 of them with two cameras.

\section{Instruments and Measures for Further Data Gathering}

At three measurement time points sketched in Fig. 2, several measures were administered:

- Measures for students' conceptual understanding of fractions. Students' mathematics achievement was operationalized as conceptual understanding of fractions (dependent variable) and measured by a fraction test (developed and standardized in a study involving 268 students in Prediger \& Wessel, 2013). The test items covered the following: specifying and drawing fractions in part-whole and partgroup models, ordering fractions according to size and explaining order in a contextual situation (e.g. dividing a cake) or graphical representations (fraction bar, rectangle, or circle), finding equivalent fractions with a given numerator/ denominator and explaining equivalence in a contextual situation or graphical representation, analyzing "part of" situations, finding locations on the number line, subtracting with proper and improper fractions, and solving word problems with fractions as operators (the last three topics were not treated in the intervention). The items in the pre-test, post-test, and follow-up-test were structured in parallel versions with changing numbers. The test has a satisfactory internal consistency, with Cronbach's $\alpha=0.834$ for the pre-test with 28 items (in a sample of $N=1120$ students), and $\alpha=0.754$ for the post-test (29 items, $N=417$ students).

- Measures for students' socioeconomic status and general cognitive ability. Students' socioeconomic status (known as a relevant factor for achievement; OECD, 2007) was measured by the book scale, an economic and reliable instrument ( $r=0.80$, Paulus, 2009). Students' general cognitive ability, more precisely the sub-construct of fluid intelligence, was measured using a matrix test (BEFKI 7, adapted from Wilhelm, Schroeders \& Schipolowski, 2014). Within our initial sample of 1124 students, the test reaches Cronbach's $\alpha$ of 0.763 . Further control variables were captured in the students' self-report questionnaire: age, gender, multilingual family socialization (operationalized by languages spoken with parents or grandparents), and immigrant status (operationalized by parents' and own country of birth).

- Measures for German and Turkish language proficiency. Students' language proficiency in Turkish and German were measured with two C-tests, a widely used, economic, and valid measure based on cloze texts (Grotjahn, Klein-Braley \& Raatz, 2002). The German C-test consisted of three texts by Daller (1999) in informal and formal language. The Turkish C-test contained informal and formal language texts was developed for the project (by the linguistic project partners Meryem Çelikkol and Jochen Rehbein) because available Turkish C-tests for native Turkish speakers were too complex for the multilingual students who had grown up in Germany. Both tests proved to be highly reliable: the Turkish C-test with $\alpha=0.874(N=254)$ and the 
German C-test with $\alpha=.774(N=1122)$. The maximum number of correctly filled gaps was 60. As all students were fluent in everyday Turkish but only 254 volunteered for reading and writing in Turkish, the Turkish C-test can be considered as sufficient to capture the language proficiency in the formal (written) registers.

\section{Initial Sample and Sample of Teaching Intervention}

The initial full sample consisted of seventh grade students $(N=1124 ; 48 \%$ female and $52 \%$ male) in 12 secondary schools in an urban metropolitan region in Germany. Three hundred and twenty-two students self-reported that they speak (among other languages) everyday Turkish at home (at $27 \%$ of the total, this group is overrepresented in the sample due to the selections of schools), with 262 agreeing to take part in the written Turkish C-test.

For the compensatory remedial interventions, only bilingual students with low achievement in mathematics (a fraction test score below 15 points) were selected. This group of Turkish/German bilingual students $(n=128)$ was stratified according to the control variables and then randomly assigned to the monolingual or bilingual intervention or the control group (Table 3).

$F$-tests comparing the three intervention groups show no significant differences with respect to mathematics achievements in the pre-test $(F[2,125]=0.962, p>.05)$, German language proficiency $(F[2,125]=0.439, p>.05)$, Turkish language proficiency $(F[2,125]=0.264, p>.05)$, and fluid intelligence $(F[2,125]=0.580, p>.05)$. As Table 3 shows, the groups were also relatively comparable with respect to age and socioeconomic status.

For the differential analysis of learning gains, the intervention sample was divided by a median split into the groups of students with low and high Turkish language proficiency with scores in the Turkish C-test of $0-25$ and $26-60$ points, respectively

Table 3 Descriptive data for the full sample and the intervention groups

\begin{tabular}{lllll}
\hline$m$ (SD) for different measures & $\begin{array}{l}\text { Full sample } \\
(N=1124, \\
N=262 \text { for } \\
\text { T C-test) }\end{array}$ & $\begin{array}{l}\text { M Monolingual } \\
\text { intervention } \\
(n=44)\end{array}$ & $\begin{array}{l}\text { B Bilingual } \\
\text { intervention } \\
(n=41)\end{array}$ & $\begin{array}{l}\text { C Control } \\
\text { group no } \\
\text { intervention } \\
(n=43)\end{array}$ \\
\hline $\begin{array}{l}\text { Mathematics achievement } \\
\quad \text { fraction pre-test) }\end{array}$ & $10.31(4.73)$ & $7.52(3.41)$ & $7.93(2.60)$ & $8.42(2.95)$ \\
$\begin{array}{l}\text { General cognitive ability } \\
\text { (BEFKI) }\end{array}$ & $7.94(3.41)$ & $7.8(2.69)$ & $7.20(2.92)$ & $7.35(2.43)$ \\
$\begin{array}{l}\text { Turkish language proficiency } \\
\text { (T C-test) }\end{array}$ & $23.95(13.17)$ & $24.18(12.44)$ & $24.83(12.60)$ & $22.93(11.61)$ \\
$\begin{array}{l}\text { German language proficiency } \\
\text { (G C-test) }\end{array}$ & $35.27(9.17)$ & $31.55(6.13)$ & $32.32(6.21)$ & $31.07(6.10)$ \\
$\begin{array}{l}\text { Age } \\
\text { Socioeconomic status SES } \\
\quad \text { (percent of low/ } \\
\text { medium/high SES) }\end{array}$ & $12.76(0.7)$ & $12.71(0.77)$ & $12.88(0.7)$ & $12.81(0.6)$ \\
\hline
\end{tabular}


(see Table 4; they are equally distributed among the groups of Table 3). By construction, these groups differ substantially in their Turkish language proficiency (34.51 vs. 14.37), whereas the differences in German language proficiency turned out to be remarkably small (32.79 vs. 30.58$)$.

\section{Methods for the Quantitative Analysis}

In light of students' limited familiarity with mathematics learning in Turkish, the varying proficiency in the formal Turkish registers, and the limited time of the intervention, two hypotheses were tested:

(H1) The five sessions of bilingual intervention are less effective for increasing students' conceptual understanding of fractions than those of the monolingual intervention.

(H2) Students with lower Turkish formal language proficiency profit less from the bilingual intervention than students with higher Turkish formal language proficiency.

In order to test these hypotheses, repeated measure analyses of variance (one-way ANOVA) were conducted with the scores of the fraction test in the pre-test, post-test, and follow-up test. Group and time were the main factors of the ANOVA and group by time was the interaction factor for the analysis, in the second case with subsamples with low and high Turkish formal language proficiency. Within these analyses of variance, the inter-group effect sizes were determined by partial eta squared. Additionally, the intragroup effect sizes $d$ were captured by determining learning gains within each group.

In a quantitative video analysis of the videotaped interventions, teachers' and students' use of Turkish or mixed language in the third sessions was captured. For this, each sentence of students and teachers was tagged with a time code and classified as German, Turkish, or mixed (operationalized on a lexical level by both languages within a sentence) in the TRANSANA data corpus (TRANSANA is the video analysis software). The sum of time intervals between tags provided the total time of language uses for each participant.

\section{Methods for the Qualitative Analysis}

In step 1 of the qualitative analysis, the video data of students' processes of conceptual development were inventoried using TRANSANA in order to select interesting

Table 4 Descriptive data for the subsamples of all intervention groups

\begin{tabular}{llll}
\hline & & $\begin{array}{l}\text { Students with } \\
\text { high Turkish } \\
\text { formal language } \\
\text { proficiency } \\
(n=61)\end{array}$ & $\begin{array}{l}\text { Students with } \\
\text { low Turkish } \\
\text { formal language } \\
\text { proficiency } \\
(n=67)\end{array}$ \\
\hline $\begin{array}{l}\text { Mathematics achievement (fraction pre-test) } \\
\text { General cognitive ability (BEFKI) }\end{array}$ & $m(\mathrm{SD})$ & $8.25(2.69)$ & $7.69(3.28)$ \\
Turkish language proficiency (T C-test) & $m(\mathrm{SD})$ & $7.59(2.76)$ & $7.33(2.61)$ \\
German language proficiency (G C-test) & $m(\mathrm{SD})$ & $34.51(6.53)$ & $14.37(7.01)$ \\
\hline
\end{tabular}


episodes for transcription. In step 2, an interpretative sequential analysis was carried out on the transcripts using a systematic extensive interpretation (Beck \& Maier, 1994) to prepare for extrapolating crucial moments and typical features in the individual and interactional processes and to identify the language use in different registers and languages. In step 3, the most conceptually dense moments in the transcripts were analyzed in depth with the analytical tools developed in Prediger and Wessel (2013), allowing identification of students' processes of constructing mathematical meanings and developing conceptual understanding. In this paper, two episodes and their analyses are briefly presented. These episodes mainly serve to explain the quantitative results, without accounting for all analytic results.

\section{Results from the Analyses of Videos and Test Scores}

\section{Results of the Quantitative Video Analysis: Home Language Resources Can Be Activated}

As a bilingual intervention was unusual for the multilingual students in our study, Q1 asks whether it is possible to engage them in bilingual discourses. Table 5 shows that with a substantial investment of the teacher (with $28 \%$ of language production time in Turkish and $39 \%$ in mixed utterances), the students can indeed be activated to speak the home language (16\% in Turkish and $15 \%$ mixed) in the context of mathematics, where they are unaccustomed to speaking it. The high share of mixed utterances in which teachers and students related their languages within one utterance is remarkable and is completely in line with the idea of connecting languages.

These results can be interpreted as the first evidence for the feasibility of multilingual learning opportunities: In sum, $45 \%$ of the time, students were exposed to Turkish or mixed language (data reported in Schüler-Meyer, Prediger, Wagner, \& Weinert, submitted). Thus, even under difficult circumstances (starting very late in Grade 7 in a German-only school system and for only five sessions), students can be activated to use their home language for mathematics learning, when also taking into consideration the students' language reception time (language production of the teacher and other students).

However, this does not yet show that the additional languages really provide a benefit for mathematics learning. In contrast, Hypothesis 1 assumes that the investment in Turkish may distract from learning mathematics, so the learning gains must be considered in a randomized control trial.

Table 5 Distribution of language production in German and Turkish by teachers and students (averages)

\begin{tabular}{lllll}
\hline & $\begin{array}{l}\text { Share of German } \\
\text { utterances }\end{array}$ & $\begin{array}{l}\text { Share of Turkish } \\
\text { utterances }\end{array}$ & $\begin{array}{l}\text { Share of mixed } \\
\text { utterances }\end{array}$ & $\begin{array}{l}\text { Total time of language } \\
\text { production }\end{array}$ \\
\hline $\begin{array}{c}\text { Teachers' language } \\
\text { productions }\end{array}$ & $32 \%$ & $28 \%$ & $39 \%$ & $99 \%$ (1\% unidentified) \\
$\begin{array}{c}\text { Students' language } \\
\text { productions }\end{array}$ & $66 \%$ & $16 \%$ & $15 \%$ & $97 \%$ (3\% unidentified) \\
\hline
\end{tabular}




\section{Learning Gains: Monolingual and Bilingual Intervention Equally Effective}

With respect to Q2, Table 6 shows achievement scores and ANOVA results for all three groups. Both teaching intervention groups show significant increases in their fraction test scores, with very high effect sizes $(d=1.08$ for the monolingual and $d=0.94$ for the bilingual intervention; all effect sizes $>0.8$ count as high). The control group also shows a significant learning gain but with a much lower effect size of $d=0.4$.

In the follow-up-test, the learning gains of the bilingual intervention group slightly increased compared to the monolingual intervention, but not significantly. In the ANOVA, the significance of the main factor "time" with $F_{(\text {time })}=93.13$ and its high effect size of $\eta^{2}=0.41$ suggests that, over the time of the teaching intervention, the students' conceptual understanding of fractions in the three groups increased.

The significant interaction effect of "group $\times$ time" suggests that the three groups developed significantly unequally from pre- to post-test: The effect size of $\eta^{2}=0.09$ hints at medium inter-group differences. The post-hoc-test does not show a pairwise difference between the monolingual and bilingual teaching intervention, but between the mono- or bilingual teaching interventions and the control group.

In summary, Hypothesis 1 is shown to be false, as the monolingual and bilingual teaching interventions were equally effective in fostering the students' conceptual understanding of fractions.

\section{Differential Learning Gains: Students with Higher Turkish Formal Language Proficiency Profit More}

In order to investigate Q3, an ANOVA for the subgroups and pairwise ad hoc tests were conducted for the subsamples with low and high Turkish formal language proficiency (TFLP) but with only small differences in German language proficiency. The results in Table 7 show that the learning gains for students with low and high TFLP differ much more for the multilingual intervention than for the monolingual intervention: Students

Table 6 Effects of two forms of intervention and control groups in pre-test, post-test, and follow-up test

\begin{tabular}{|c|c|c|c|c|c|}
\hline & $\begin{array}{l}\text { Scores in } \\
\text { pre-test } m \\
(\mathrm{SD})\end{array}$ & $\begin{array}{l}\text { Scores in } \\
\text { post-test } m \\
\text { (SD) }\end{array}$ & $\begin{array}{l}\text { Scores in } \\
\text { follow-up } \\
\text { test } m(\mathrm{SD})\end{array}$ & $\begin{array}{l}\text { Effect size } d \\
\text { for pre- to } \\
\text { post-test }\end{array}$ & $\begin{array}{l}\text { Effect size } d \\
\text { for pre-test to } \\
\text { follow up }\end{array}$ \\
\hline $\begin{array}{l}\text { Monolingual intervention } \\
\qquad(n=44)\end{array}$ & $7.52(3.41)$ & $11.57(3.46)$ & $10.98(3.24)$ & 1.18 & 1.04 \\
\hline $\begin{array}{l}\text { Bilingual intervention } \\
\quad(n=41)\end{array}$ & $7.93(2.60)$ & $10.88(3.38)$ & $11.27(4.72)$ & 0.99 & 0.91 \\
\hline $\begin{array}{l}\text { Control group: No intervention } \\
\quad(n=43)\end{array}$ & $8.42(2.95)$ & $9.4(3.57)$ & $10.74(3.67)$ & 0.3 & 0.7 \\
\hline $\begin{array}{l}\text { Inter-group and time effect } \\
\text { (for pre- to post-test) }\end{array}$ & \multicolumn{5}{|c|}{$\begin{array}{l}F_{(\text {time })}=93.13, p<.001, \eta^{2}=0.41 ; F_{(\text {group })}=0.3(\mathrm{~ns}), \eta^{2}=0.005 \\
\quad F_{(\text {group }} \times \text { time) } \\
=6.83, p<.01, \eta^{2}=0.09\end{array}$} \\
\hline $\begin{array}{l}\text { Inter-group and time effect } \\
\text { (for pre- to follow-up test) }\end{array}$ & \multicolumn{5}{|c|}{$\begin{array}{l}F_{(\text {time })}=63.66, p<.001, \eta^{2}=0.34 ; F_{(\text {group })}=0.43(\mathrm{~ns}), \eta^{2}=0.007 \\
\quad F_{(\text {group } \times \text { time })}=4.91, p<.01, \eta^{2}=0.07\end{array}$} \\
\hline
\end{tabular}

$n s$ not significant 
Table 7 Comparison of students with high and low TFLP in pre- and post-test

\begin{tabular}{|c|c|c|c|c|c|}
\hline & $\begin{array}{l}\text { Scores in } \\
\text { pre-test } m \\
(\mathrm{SD})\end{array}$ & $\begin{array}{l}\text { Scores in } \\
\text { post-test } m \\
\text { (SD) }\end{array}$ & $\begin{array}{l}\text { Scores in } \\
\text { follow-up } \\
\text { test } m(\mathrm{SD})\end{array}$ & $\begin{array}{l}\text { Gains in } \\
\text { average scores } \\
\text { from pre-test to } \\
\text { follow-up }\end{array}$ & $\begin{array}{l}\text { Intra-group } \\
\text { effect-size } d \\
\text { from pre-test } \\
\text { to follow-up }\end{array}$ \\
\hline $\begin{array}{l}\text { Monolingual intervention for } \\
\text { high TFLP }(n=22)\end{array}$ & $7.91(3.05)$ & $11.96(3.96)$ & $11.59(2.92)$ & $\Delta=3.68$ & $d=1.23$ \\
\hline $\begin{array}{l}\text { Monolingual intervention for } \\
\text { low TFLP }(n=22)\end{array}$ & $7.14(3.77)$ & $11.18(2.92)$ & $10.36(3.49)$ & $\Delta=3.22$ & $d=0.89$ \\
\hline $\begin{array}{l}\text { Bilingual intervention for } \\
\text { high TFLP }(n=20)\end{array}$ & $8.1(2.47)$ & $11.55(3.35)$ & $12.75(5.14)$ & $\Delta=4.65$ & $d=1.22$ \\
\hline $\begin{array}{l}\text { Bilingual intervention for } \\
\text { low TFLP }(n=21)\end{array}$ & $7.76(2.77)$ & 10.24 & $9.86(3.90)$ & $\Delta=2.10$ & $d=0.63$ \\
\hline $\begin{array}{l}\text { Inter-group and time effect } \\
\text { from pre- to post-test }\end{array}$ & \multicolumn{5}{|c|}{$\begin{array}{l}F_{(\text {time })}=91.63, p<.001, \eta^{2}=0.43 ; F_{(\text {group })}=0.64, p=.67(\mathrm{~ns}), \eta^{2}=0.03 \\
\quad F_{(\text {group x time) }}=4.49, p<.01, \eta^{2}=0.16\end{array}$} \\
\hline
\end{tabular}

ns not significant

with low TFLP gain $\Delta=3.2$ in the monolingual intervention (with an effect size of $d=0.89)$, whereas students with high TFLP gain $\Delta=3.68(d=1.23)$. In contrast, students with high TFTP in the multilingual intervention gain $\Delta=4.65$ (the high standard deviation results in an effect size of $d=1.22$ ), while their peers with low TFLP gain only $\Delta=2.10(d=0.63)$. The unequal development of the groups with different TFLP is also confirmed by the significant interaction effect group $\times$ time $\left(F_{\text {(group } \times \text { time })}=4.49, p<.01, \eta^{2}=0.16\right)$, even if the small sample sizes do not allow the post hoc test to show pairwise significant group differences.

In summary, the quantitative data tend to confirm $\mathrm{H} 2$, i.e. students with higher TFLP profit substantially more in their conceptual understanding of fractions from the bilingual intervention than students with lower TFLP. The much smaller difference between students with high and low TFLP in the monolingual intervention underlines that the differential effects of the multilingual intervention are not connected to general cognitive factors or the German language proficiency gap.

These quantitative results call for a qualitative investigation into why students' low TFLP limits the benefits of the specific short-term bilingual learning opportunities.

\section{Qualitative Insights into Bilingual Learning Processes: Obstacles Can Be Overcome}

This section illuminates how a bilingual discourse can be established and explains why Hypothesis 1 must be rejected, although Turkish can also pose additional obstacles that can then be overcome by some students, depending on their formal language proficiencies.

The transcript of Episode 1 in Table 8 is taken from the first teaching intervention session, i.e. the first encounter where Turkish was used for mathematical discussions. Akasya, Halim, Hakan, and Ilknur discuss Emily's (a fictitious student) statement: "If 3 of 5 fields in a fraction bar are colored green, then this is a 3/5 share." The students are asked to reflect if this (correct) statement is correct or incorrect. Akasya starts by reading out Emily's statement in Turkish, where the fraction is denoted as " 5 thereof 3." 
Table 8 Transcript of Episode 1: How to read fractions in Turkish

\begin{tabular}{|c|c|c|}
\hline Turn/Person & $\begin{array}{l}\text { Original } \\
\text { (Turkish in black, German in grey) }\end{array}$ & $\begin{array}{l}\text { English Translation } \\
\text { (from Turkish black, from German grey) }\end{array}$ \\
\hline 01 Akasya & Beşte üç. & Five therein three. \\
\hline 02 Halim & Üçte beşi. & Three therein five. \\
\hline 03 Hakan & Beşte üç. & Five therein three. \\
\hline 04 Teacher & Üçte beş? & Three therein five? \\
\hline 05 Ilk. \& Aka. & Beşte üç [protesting]! & Five therein three! [protesting] \\
\hline 06 Teacher & Üçte beş derken ne olur? & What happens if you say three therein five? \\
\hline 07 Ilknur & Beşte üç! & Five therein three! \\
\hline 08 Halim & Fünf Drittel. & Five thirds. \\
\hline 09 Hakan & Drei Fünftel. & Three fifths. \\
\hline 10 Ilknur & Drei Fünftel, Fünfte Drittel. & Three fifths. Fifth third? \\
\hline 11 Halim & $\begin{array}{l}\text { Fünf Drittel, ama- ima- immer umgekehrt } \\
\text { immer eins, eins- [gestures] }\end{array}$ & $\begin{array}{l}\text { Five third, but al, always the other way around } \\
\text { [gestures fingers from bottom to top in the air] } \\
\text { always one, one- }\end{array}$ \\
\hline 12 Ilknur & Çok bilmiş. & know-it-all. \\
\hline 13 Teacher & Üçte beş, peki üçte beş deyince ne diyoruz? & $\begin{array}{l}\text { Three therein five, so what do we say, mean when } \\
\text { we say three therein five? }\end{array}$ \\
\hline 14 Halim & $\mathrm{Ja}$, fünf Drittel. & Yes, five third. \\
\hline 15 Ilknur & Beş tane Teil, und üç tane anmalen & Five parts part, and three pieces painting. \\
\hline 16 Akasya & Drei Fünftel. & Three fifths. \\
\hline 17 Halim & Fünf Drittel. & Five thirds. \\
\hline 18 Teacher & Üçte beş? .. üçten beş? & Three therein five? Three thereof five? \\
\hline 19 Halim & Ja fünf Drittel. & Yes, five thirds. \\
\hline 20 Teacher & $\begin{array}{l}\text { Üçten beş, hadi diyelim üçten beşini boya, } \\
\text { üçten beşini boya, oluyo mu? }\end{array}$ & $\begin{array}{l}\text { Three thereof five, now let's say: paint three thereof } \\
\text { five, paint three thereof five, does it work? }\end{array}$ \\
\hline 21 Halim & Drei Stück anmale—-he! Geht doch gar nicht! & Painting three pieces- he! That does not work at all! \\
\hline 22 Student & $\ldots$ & \\
\hline 23 Ilknur & Nein, BEŞTEN üçü boyican & No, you have to paint FIVE thereof three. \\
\hline 24 Akasya & Beşten üçü oluyo ama üçte beşi olmuyo. & $\begin{array}{l}\text { Five thereof three works but three therein five does } \\
\text { not work. }\end{array}$ \\
\hline 25 Teacher & Ahaa, neden üçte beşi olmuyo? & Ahaa, and why does three therein five not work? \\
\hline 26 Ilknur & Weil drei ist weniger als fünf. & Because three is less than five. \\
\hline 27 Akasya & $\begin{array}{l}\text { Üçün içine beş sığmıyo, ama beşin içine üç } \\
\text { sığıyo. }\end{array}$ & $\begin{array}{l}\text { In three, the five do not fit into, but in five, three does } \\
\text { fit into. }\end{array}$ \\
\hline
\end{tabular}

In this episode, the students negotiate how to express fractions in Turkish. The fact that Halim is confused by the different reading orders (Turns 1-11) leads to a clarification (Turns 13-27), which may result in a deepened understanding of fractions for all four students, which Halim shows some turns later. This illustrates how a learning process in the relating registers approach might unfold by referring to the fraction bar (which had only been mentally represented at that point; Fig. 3) and both languages. The students relate the academic Turkish register to the formal German register and the everyday Turkish register (beşten üç, meaning "thereof," instead of "therein"), which is later mediated within the graphical register. Guided by their

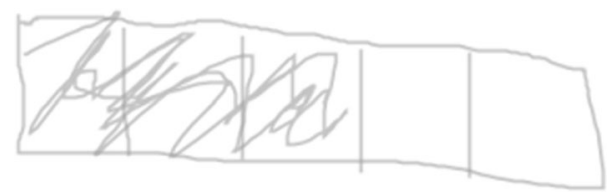

Fig. 3 Fraction bar of three fifths as mentally represented by Ilknur 
teacher, the students then reflect on the meaning of "3 therein 5." To do that, the students translate the fractions into their German equivalents: fünf Drittel (five thirds) and drei Fünftel (three fifths) (Turns 6-14). However, on the discursive level, the negotiations in these turns are quite limited, as the students simply name the fractions in both directions. This changes when Ilknur introduces an (imagined) graphical representation of fractions (Turn 15): This allows the students to discuss how to mentally represent the fractions $3 / 5$ and 5/3 in a fraction bar (Turns 15-27). In Turns 23 and 24, the girls Ilknur and Akasya refer to the Turkish everyday suffix -ten ("thereof," not specifically referring to something) in order to understand the formal Turkish suffix -te ("therein," more formally referring to something). With respect to students' conceptual understanding, the "inverse" reading direction of Turkish fractions - namely, the verbal spelling out of the vertical symbolic and even horizontal slash-mode sign-is a conceptual obstacle that does not appear in the monolingual intervention.

In this episode, students struggle with two different interpretations of the Turkish expression "5 therein 3," namely, $5 / 3$ and $3 / 5$. The first interpretation seems to be viable to the students because they work within the reference context of the German way of expressing a fraction as "three fifths," where the part is expressed first. In line with this German reference context, the students interpret " 5 therein 3 " as "five thirds." Only by exchanging the German reference context for the fraction bar as new reference context can the students interpret " 5 therein 3 " using the Turkish everyday suffixes "thereof" and as a way of expressing the parts within the whole (introduced by Ilknur in Turns 15 and 23). In the later course of the intervention, this Turkish conceptualization is their solid resource for conceptual development.

This episode provides examples that back two crucial points of the argument in this paper. First, with respect to Q2 and Q3, this episode illustrates how some students can struggle with the formal Turkish register: In this case, it is Halim who also struggles in German. In the first section (Turns 1-14), we see how the students discuss $3 / 5$ and 5/3 artificially, without relating to the meaning of these fractions. In these moments, it seems that the formal Turkish language for expressing fractions does not yet have a meaning for the students, and the discursive resources for discussing it in Turkish are too limited. However, when relating to the fraction bar and to gestures, as intended in the relating registers approach, the students can explain their thinking about how to read the formal Turkish expression "5 therein 3" in a meaningful way (Turns $23 \mathrm{ff}$ ). Interestingly, relating registers occurs in a translanguaging mode, as both languages are used synthetically (Grosjean, 2001; House \& Rehbein, 2004). This is one specific way of mixing languages; others have been found in other transcripts.

In addition, collaboratively working on how to read fractions in a bilingual teaching intervention takes time, so the beginning discussion leaves less time for the mathematical task than in a monolingual teaching intervention. This discussion (Turns 1-14) does not directly contribute to solving the underlying conceptual problem. However, having to distinguish different reading directions leads to a deeper understanding of, in this case, the meanings of numerator and denominator. On a more general note, it seems that this reflection on the reading direction seems to support students to flexibly change their perspective of fractions towards the part-of-whole concept.

In Episode 2, some minutes later, the four students discuss a second fictional student's utterance, which this time is wrong. Paul says, "When I draw a 3/5 share in the fraction bar, then 3 fields are colored and 5 stay white." The analysis of Episode 2 
(extensive analysis from a linguistic perspective in Wagner et al., 2017) shows that the four students can later rely on the Turkish conceptualization as being more convincing in emphasizing the referent whole (Table 9).

When Halim evaluates Paul's utterance in the new task as correct (Turn 1), the other students contradict. Although the discourse starts in German (Turns 1-4), Hakan switches to Turkish to explain why Paul and Halim are wrong: By speaking Turkish, he makes use of the Turkish reading direction of fractions. He first refers to the referent whole (5; Turn 5) and then to the part (3; Turn 7), showing that only 2 are left, not 5 (in Turn 9). For him, the part-of-whole concept may be more accessible in Turkish. In his argument, Hakan interprets Paul's utterance about $3 / 5$ by activating the Turkish conceptualization of fractions (not only the order of speaking; Turns 7-9). Hakan activates Turkish without the teacher's prompting and adopts the Turkish conceptualization of fractions to build his argument about the part-of-whole concept. He does not, however, switch to Turkish because Halim might understand him better, as in this episode Halim speaks only German, indicating that this is his preferred language here.

In sum, the two episodes provide some insights into a pattern that we find in many more transcripts of the same and other students. They offer insights into a qualitative treatment for all three research questions: With respect to Q1 and Q2, we see in many transcripts that the students are able to get involved in mathematical discourses despite having no experience with discussing mathematics in Turkish. They are repeatedly able to solve mathematical tasks by activating their Turkish language in a "bilingual mode," which is more than juxtaposing the languages (Grosjean, 2001), even within the first encounter in Session 1. With respect to Q3, it is interesting to relate the students' repeated roles in the discourses to their Turkish C-test scores (in the complete intervention sample for 128 students, the

Table 9 Transcript of Episode 2: Explaining with the Turkish fraction

\begin{tabular}{|c|c|c|}
\hline Turn/Person & $\begin{array}{l}\text { Original } \\
\text { (Turkish in black, German in grey) }\end{array}$ & $\begin{array}{l}\text { English Translation } \\
\text { (from Turkish in black, from German in grey) }\end{array}$ \\
\hline 1 Halim & Ey ist richtig! & [Reads Paul's answer again] Ey is right! \\
\hline 2 Hakan & Was laberst du? & What are you babbling? \\
\hline 3 Teacher & $\begin{array}{l}\text { Genau, wenn du sagst, das ist richtig, dann } \\
\text { male mal ein Bild dazu. }\end{array}$ & Ok, if you say it is right, draw a picture of it. \\
\hline 4 Ilknur & $\begin{array}{l}\text { Hä? Wenn man drei anmalt, wie bleiben } \\
\text { fünf übrig? }\end{array}$ & Hä? If one colors three, how can there be five left? \\
\hline 5 Hakan & $\begin{array}{l}\text { Beşte üçünü boyyom, beş kalmıyo o } \\
\text { zaman. }\end{array}$ & $\begin{array}{l}\text { Five therein three I color, so five aren't left. } \\
\text { [Points at the picture he started to paint }]\end{array}$ \\
\hline 6 Halim & Ach fu- oh- shi- & Ach fu- oh shi- \\
\hline 7 Hakan & $\mathrm{Al}$, üç tene boyyom & 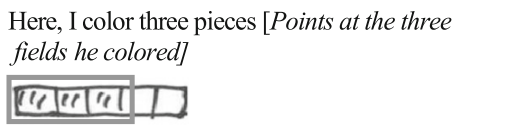 \\
\hline 8 Halim & Nein ist doch! Hä? & No, it is! Eh? [irritated] \\
\hline 9 Hakan & $\mathrm{Al}$, daha beş tane beyaz mı var, iki dene var & $\begin{array}{l}\text { Here, there are not five white pieces left, there } \\
\text { are only two [Points at white parts that are left]. }\end{array}$ \\
\hline
\end{tabular}


score was $m=24.2$ with $S D=12.2$ and $\max =49$ ). All four students have above average scores, but with differences of 1 or 1.5 SD: Hakan's score is 44, Akasya's and Ilknur's are 31, and Halim's is 26. As in many other episodes, the discourse in Episode 1 is dominated by Akasya and Ilknur (Turns 23ff), who have medium TFLP among the four students. Thus, there is no direct connection between TFLP and participation.

Hakan who has the highest TFLP among the four students is rarely as active as in Episode 2. For the most part, he participates less actively, as in Episode 1, but he is very attentive and involved at critical moments. His strong learning gains (while the full sample had $m=10.31$ and $\mathrm{SD}=4.73$ in the pre-test, Hakan increased from a pre-test score of 7 to a follow-up score of 17) are also the best example for learning by language reception instead of active participation. Halim has the lowest TFLP among the four and also low German language proficiency. He seems to struggle most to express his ideas (Episode 1, Turns 19, 21), and this is also reflected by his very limited learning gains (from 8 to 9). In other episodes, these patterns are also relatively stable in the analyzed group.

\section{Discussion}

\section{Central Results and Limitations}

The presented study contributes to the research on fostering subject-matter-integrated language learning in mathematics. While there are institutional arguments for both monolingual (e.g. lack of qualified multilingual teachers in Germany) and bilingual teaching interventions (Cummins, 2000; Planas, 2014; Reljić et al., 2015), the reported results suggest that both types of teaching interventions can be at least equally effective, even under difficult circumstances where Turkish is initially non-functional for mathematics.

With respect to Q1, an existence proof was provided that it is possible to establish a bilingual teaching-learning process for multilingual seventh graders on fractions, despite the students' limited experience with the technical register in Turkish (Q1). The quantitative video analysis on the percentages of chosen languages shows that when the teachers invest in Turkish and a mixed language, the students also start using them, in spite of all barriers of language dominances and the late start in Grade 7 (Meyer et al., 2016). The quantitative investigation of language use has its limitations, as it gives no insights into the qualitative use of languages, for example, the phenomena of code-switching within an utterance (e.g. Turns 15, 23; Table 8) or use of Turkish grammar in a German utterance. It is, however, a means to investigate whether a bilingual teaching intervention can successfully promote the use of Turkish. Further research is required to clarify these modes of using mixed languages and relate to different modes of translanguaging in more detail.

With respect to Q2, the corresponding bilingual Turkish/German and monolingual German teaching interventions lead to comparable results in terms of fostering multilingual students' conceptual understanding of fractions (Q2). At least four competing explanation hypotheses can be formulated to explain the non-significance of differences and need further investigation: 
(1) Sample sizes too small: There is a difference with low effect size which may become more visible with larger sample sizes. [This hypothesis assumes that the monolingual intervention is more effective, for which there is almost no external evidence in the literature (see Reljić et al., 2015)].

(2) Too little individual use of Turkish: The average time of Turkish or mixed language use was quite high at $45 \%$, but students used the Turkish language much less, and it is possible that this is a reason for limited learning gains. Thus, in future research, the correlation between individual Turkish language use and the individual learning gains must be investigated on the students' individual level.

(3) Intervention too short: As Grade 7 is late to start bilingual mathematics learning, the short intervention time of $5 \times 90$ min may be a reason that the multilingual intervention did not provide higher learning gains; in light of the political nature of language (Setati, 2005), students may need time to accept and get adapted to Turkish as a language of learning.

(4) Little difference in mathematics learning gains: If other studies are able to replicate the results presented here, it may be sensible to hypothesize that it is not important for mathematical learning gains whether the intervention mobilizes multilingual resources or not. Bilingual learning can then be established for other reasons, such as identity building and motivation, without negative effects on conceptual learning.

The qualitative analysis in the last section provides some deeper insights into the processes of using Turkish and mixed language in a bilingual teaching intervention. It shows barriers where students initially need to establish means to coordinate languages and conceptualizations. Episode 1 may be an example of the concern about time-on-task: Becoming adapted to a bilingual learning situation requires more time than a monolingual situation does. However, this example also provides more insights: More individual use of Turkish may help students to get more used to such "needs for conceptual coordination," strengthening the second explanation hypothesis mentioned above. In light of the time needed to establish Turkish as a language of learning (Hypothesis 3), getting used to "needs for conceptual coordination" may take more time than five 90 -min sessions. Those students who participate regularly or have a higher TFLP may adapt to this need faster, which may explain why both the monolingual and bilingual intervention lead to comparable learning outcomes, especially for students with high TFLP (see Table 7; discussion below). Episode 2 and many other transcripts not analyzed in this paper illustrate that Turkish is not so much a barrier, but a learning opportunity for fostering involvement. This suggests that the hypothesis that the monolingual intervention is more effective has little substance on the level of learning processes. The use of Turkish or mixed language is then not so much an issue of limited time-on-task but of providing students with an additional means for understanding fractions by coordinating and reflecting their conceptualizations in the different languages and of learning to flexibly use the most appropriate conceptualization. From this perspective, Turns 1-14 (Table 8) show the students searching for means to coordinate a conceptualization of fractions, which in the long run fosters conceptual understanding.

With respect to Q3, differential learning gains have been shown: Students with lower TFLP seemed to profit less from the bilingual teaching intervention than their peers with higher proficiency, so the title question of the article, "Is formal language 
proficiency in the home language required to profit from a bilingual teaching intervention in mathematics?" must be answered with "No, it is not required, but it helps." The qualitative analysis suggests that the technical register is much less relevant than the academic register, and both may be only two among other factors, as some students (even those with low TFLP) engage more in the discourse while others engage less. The multi-faceted learning processes in the two episodes indicate that the C-test may also not be the adequate instrument to capture the students' bilingual language proficiency, because it measures students' written language proficiency in only one language without taking into account their oral bilingual discourse competence, which includes translanguaging for participating in bilingual teaching-learning processes.

\section{Further Research Perspectives}

The observations of differential learning gains require further investigations starting from different hypotheses:

- First, it may be that the Turkish teaching material and the teacher favor students with high TFLP. The teacher, as an expert Turkish speaker, may engage more often with students with high TFLP, as they are more fluent. As a consequence, these students may have more slots to participate in the mathematical discourse and to engage in complex discourse practices such as negotiating meanings. Other studies have shown that English language learners need to be positioned as competent so that they can participate productively (Turner, Domínguez, Empson \& Maldonado, 2013), and these positionings may be mediated by students' home language proficiency. Thus, issues of proficiency and their relation to positionings and identities must be investigated in further studies.

- Second, it may be that the test formats employed in this study do not capture students' competencies, as these tests are monolingual and thus do not allow for translanguaging and a mix of Turkish and German. In the future, specific multilingual test formats may be required for testing the students' bilingually represented conceptual understanding. In light of this, we intend to analyze the oral data in order to evaluate students' translanguaging proficiency rather than assuming two singlelanguage proficiencies.

- Third, in a bilingual intervention, students with low TFLP may not be able to follow bilingual conversations with the same depth that they can follow monolingual ones. They may also have fewer learning opportunities for more abstract and decontextualized discourses in out-of-school contexts. Alternatively, they may not be able to exercise agency to change the classroom discourse towards their learning needs (Langer-Osuna, Moschkovich, Norén, Powell \& Vazquez, 2016). Thus, future interdisciplinary studies should investigate how low TFLP interferes with discourse competency and should also address in more detail the role of German language proficiency in its interplay with Turkish language proficiency. Furthermore, opportunities for agency in implementing a teaching intervention should be investigated.

These points illustrate that it is not yet clear whether changes in the teaching material, teaching practices, or students' ways of participating in the discourse can 
overcome the issue that students with lower TFLP seem to profit less from a bilingual teaching intervention.

Beyond these open questions, the presented empirical study is methodologically limited by the small number of students in the bilingual and monolingual interventions. The resulting tendencies must therefore be interpreted and generalized with caution. Furthermore, the learning outcomes were only measured using German tests, so that the test may have artificially contributed to the effect that students with low TFLP profited less from the intervention. In addition, implementation control is required to investigate how the intended learning trajectory was put into praxis, and whether the teachers in the intervention differed in this regard.

However, even if this study is limited in different aspects, and the results invite further investigation, it is already encouraging to see that the widely claimed call for bilingual learning opportunities are also realizable in countries such as Germany that do not have traditions of bilingual teaching and learning. This may be enough reason to start the process of change towards multilingual classrooms, for which so many cultural and political reasons exist (Barwell, 2009).

Acknowledgements The project "MuM-Multi: Fostering Language in multilingual mathematics classrooms effects and conditions of a content- and language integrated intervention" is funded by the German minis try BMBF (grant 01JM1403A, grant holder S. Prediger, Jochen Rehbein and A. Redder). We thank our partners Jochen Rehbein, Jonas Wagner, and Meryem Çelikkol for the insightful interdisciplinary cooperation in the project.

Open Access This article is distributed under the terms of the Creative Commons Attribution 4.0 International License (http://creativecommons.org/licenses/by/4.0/), which permits unrestricted use, distribution, and reproduction in any medium, provided you give appropriate credit to the original author(s) and the source, provide a link to the Creative Commons license, and indicate if changes were made.

\section{References}

Adler, J. (2001). Teaching mathematics in multilingual classrooms. Dordrecht, The Netherlands: Kluwer.

Auer, P. (2010). Code-switching/mixing. In R. Wodak, B. Johnstone, \& P. E. Kerswill (Eds.), The SAGE handbook of sociolinguistics (pp. 460-478). London, England: Sage.

Bartolini Bussi, M. G., Baccaglini-Frank, A., \& Ramploud, A. (2014). Intercultural dialogue and the history and geography of thought. For the Learning of Mathematics, 34(1), 31-33.

Barwell, R. (Ed.). (2009). Multilingualism in mathematics classrooms. Bristol, England: Multilingual Matters.

Beacco, J.-C., Byram, M., Cavalli, M., Coste, D., Egli Cuenat, M., Goullier, F., \& Panthier, J. (2010). Guide for the development and implementation of curricula for plurilingual and intercultural education. Strasbourg, France: Council of Europe. Retrieved from http://www.coe.int/lang.

Beck, C., \& Maier, H. (1994). Zu Methoden der Textinterpretation in der empirischen mathematikdidaktischen Forschung [About methods of text interpretation in empirical mathematics education research]. In $\mathrm{H}$. Maier \& C. Beck (Eds.), Verstehen und Verständigung (pp. 43-76). Köln, Germany: Deubner.

Clarke, D. J. (2013). Contingent conceptions of accomplished practice: The cultural specificity of discourse in and about the mathematics classroom. ZDM-Mathematics Education, 45(1), 21-33.

Clarkson, P. (2006). Australian Vietnamese students learning mathematics: High ability bilinguals and their use of their languages. Educational Studies in Mathematics, 64(2), 191-215.

Cummins, J. (2000). Language, power and pedagogy. Clevedon, England: Multilingual Matters.

Daller, H. (1999). Migration und Mehrsprachigkeit [Migration and multilinguality]. Frankfurt, Germany: Peter Lang.

Domínguez, H. (2011). Using what matters to students in bilingual mathematics problems. Educational Studies in Mathematics, 76(3), 305-328. 
Duval, R. (2006). A cognitive analysis of problems of comprehension in a learning of mathematics. Educational Studies in Mathematics, 61(1-2), 103-131.

Freudenthal, H. (1991). Revisiting mathematics education. China lectures. Dordrecht, The Netherlands: Kluwer.

Gathercole, V. C. M. (2002). Monolingual and bilingual acquisition. In D. K. Oller \& R. E. Eilers (Eds.), Language and literacy in bilingual children (pp. 220-252). Clevedon, England: Multilingual Matters.

Gibbons, P. (2002). Scaffolding language, scaffolding learning. Portsmouth, England: Heinemann.

Gogolin, I. (2011). Bilingual education. In J. Simpson (Ed.), The Routledge handbook of applied linguistics (pp. 229-242). London, England: Routledge, Taylor \& Francis.

Grießhaber, W., Özel, B., \& Rehbein, J. (1996). Aspekte von Arbeits- und Denksprache türkischer Schüler [Aspects of language of work and language of thinking of Turkish students]. Unterrichtswissenschaft, 24(1), 3-20.

Grosjean, F. (2001). The bilingual's language modes. In J. Nicol (Ed.), One mind, two languages: Bilingual language processing (pp. 1-22). Malden, MA: Blackwell.

Grotjahn, R., Klein-Braley, C., \& Raatz, U. (2002). C-test: An over-view. In J. A. Coleman, R. Grotjahn, \& U. Raatz (Eds.), University language testing and the C-test (pp. 93-114). Bochum, Germany: Finkenstaedt.

Haag, N., Heppt, B., Stanat, P., Kuhl, P., \& Pant, H. A. (2013). Second language learners' performance in mathematics. Learning and Instruction, 28, 24-34.

House, J., \& Rehbein, J. (2004). What is 'multilingual communication'? In J. House \& J. Rehbein (Eds.), Multilingual communication (pp. 1-18). Amsterdam, The Netherlands: John Benjamins.

Langer-Osuna, J. M., Moschkovich, J., Norén, E., Powell, A. B., \& Vazquez, S. (2016). Student agency and counter-narratives in diverse multilingual mathematics classrooms: Challenging deficit perspectives. In R. Barwell, P. Clarkson, A. Halai, M. Kazima, J. Moschkovich, N. Planas, M. Setati-Phakeng, P. Valero, \& M. Villavicencio Ubillús (Eds.), Mathematics education and language diversity. New ICMI study series (pp. 163-173). Cham, Switzerland: Springer.

Leseman, P. M., Scheele, A. F., Mayo, A. Y., \& Messer, M. (2009). Bilingual development in early childhood and the languages used at home: Competition for scarce resources? In I. Gogolin \& U. Neumann (Eds.), The bilingualism controversy (pp. 289-316). Wiesbaden, Germany: VS.

Lesh, R. (1979). Mathematical learning disabilities. In R. Lesh, D. Mierkiewicz, \& M. Kantowski (Eds.), Applied mathematical problem solving (pp. 111-180). Columbus, OH: ERIC/SMEAC.

MacSwan, J., \& Rolstad, K. (2010). The role of language in theories of academic failure for linguistic minorities. In P. J. Petrovic (Ed.), International perspectives on bilingual education (pp. 173-195). Charlotte, NC: Information Age.

Meyer, M. \& Prediger, S. (2011). The use of first language Turkish as a resource - A German case study. In M. Setati, T. Nkambule, \& L. Goosen (Eds.), Proceedings of ICMI Study 21 conference: Mathematics and language diversity (pp. 225-234). São Paulo, Brazil: ICMI.

Meyer, M., Prediger, S., César, M., \& Norén, E. (2016). Making use of multiple (non-shared) first languages: State of and need for research and development in the European language context. In R. Barwell, P. Clarkson, A. Halai et al. (Eds.). Mathematics education and language diversity. ICMI Study 21 (pp. 4766). Cham, Switzerland: Springer.

Moschkovich, J. (1999). Supporting the participation of English language learners in mathematical discussions. For the Learning of Mathematics, 19(1), 11-19.

Moschkovich, J. (2002). A situated and sociocultural perspective on bilingual mathematics learners. Mathematical Thinking and Learning, 4(2-3), 189-212.

Moschkovich, J. (2013). Principles and guidelines for equitable mathematics teaching practices and materials for English language learners. Journal of Urban Mathematics Education, 6(1), 45-57.

Norén, E. (2015). Agency and positioning in a multilingual mathematics classroom. Educational Studies in Mathematics, 89(2), 167-184.

Organisation for Economic Co-operation and Development (2007). Science competencies for tomorrow's world (PISA 2006) (Vol. 2). Paris, France: OECD.

Paulus, C. (2009). Die Bücheraufgabe zur Bestimmung des kulturellen Kapitals bei Grundschülern [The book-task for determining the cultural capital of elementary school students]. Retrieved from http://hdl. handle.net/20.500.11780/3344.

Planas, N. (2014). One speaker, two languages: Learning opportunities in the mathematics classroom. Educational Studies in Mathematics, 87(1), 51-66.

Planas, N., \& Setati, M. (2009). Bilingual students using their languages in the learning of mathematics. Mathematics Education Research Journal, 21(3), 36-59. 
Prediger, S., \& Wessel, L. (2013). Fostering German language learners' constructions of meanings for fractions: Design and effects of a language- and mathematics-integrated intervention. Mathematics Education Research Journal, 25(3), 435-456.

Prediger, S., Clarkson, P., \& Boses, A. (2016). Purposefully relating multilingual registers: building theory and teaching strategies for bilingual learners based on an integration of three traditions. In R. Barwell, P. Clarkson, A. Halai, M. Kazima, J. Moschkovich, N. Planas, M. Setati-Phakeng, P. Valero, \& M. Villavicencio Ubillús (Eds.), Mathematics education and language diversity. New ICMI Study Series (pp. 193-215). Cham, Switzerland: Springer International Publishing. https://doi.org/10.1007/978-3-31914511-2

Reljić, G., Ferring, D., \& Martin, R. (2015). A meta-analysis on the effectiveness of bilingual programs in Europe. Review of Educational Research, 85(1), 92-128.

Rossell, C.H. \& Kuder, J. (2005). Meta-murkey: A rebuttal to recent meta-analysis of bilingual education. In Arbeitsstelle interkulturelle Konflikte und gesellschaftliche Integration (AKI), The effectiveness of bilingual school programs for immigrant children (pp. 43-76). Berlin, Germany: Center for Social Scienes.

Schleppegrell, M. J. (2004). The language of schooling. Mahwah, NJ: Lawrence Erlbaum.

Secada, W. G. (1992). Race, ethnicity, social class, language and achievement in mathematics. In D. A. Grouws (Ed.), Handbook of research on mathematics teaching and learning (pp. 623-660). New York, NY: Macmillan.

Setati, M. (2005). Power and access in multilingual mathematics classrooms. In M. Goos, C. Kanes, \& R. Brown (Eds.), Proceedings of the fourth international mathematics education and society conference (pp. 7-18). Gold Coast, Australia: Griffith University.

Setati, M., \& Adler, J. (2001). Between languages and discourses: Language practices in primary multilingual mathematics classrooms in South Africa. Educational Studies in Mathematics, 43(3), 243-269.

Setati, M., Molefe, T., \& Langa, M. (2008). Using language as a transparent resource in the teaching and learning of mathematics in a grade 11 multilingual classroom. Pythagoras, 67, 14-25.

Slavin, R. E., \& Cheung, A. (2005). A synthesis of research on language of reading instruction for English language learners. Review of Educational Research, 75(2), 247-284.

Snow, C. E., \& Uccelli, P. (2009). The challenge of academic language. In D. R. Olson \& N. Torrance (Eds.), The Cambridge handbook of literacy (pp. 112-133). Cambridge, England: Cambridge University Press.

Swain, M. (1985). Communicative competence: Some roles of comprehensible output in its development. In S. Gass \& C. Madden (Eds.), Input in second language acquisition (pp. 235-256). Rowley, MA: Newbury.

Turner, E. E., Domínguez, H., Empson, S., \& Maldonado, L. A. (2013). Latino/a bilinguals and their teachers developing a shared communicative space. Educational Studies in Mathematics, 84(3), 349-370.

Wagner, J., Kuzu, T., Redder, A. \& Prediger, S. (2017). Vernetzung von Sprachen und Darstellungen in einer mehrsprachigen Matheförderung - linguistische und mathematikdidaktische Fallanalysen [Relating languages and representations in a multilingual mathematics intervention - case analyses]. Zeitschrift Fachsprache (in press).

Wilhelm, O., Schroeders, U., \& Schipolowski, S. (2014). Berliner Test zur Erfassung fluider und kristalliner Intelligenz (BEFKI 8-10) [Berlin test for determining fluid and crystallized intelligence (BEFKI 8-10)]. Göttingen, Germany: Hogrefe. 